\title{
Population densities and conservation status of Norfolk Island forest birds
}

\author{
GUY DUTSON
}

\section{Summary}

Three weeks of intensive surveys in Norfolk Island National Park in 2009 failed to find Whitechested White-eye Zosterops albogularis and it was calculated that there was a less than $17 \%$ probability that a population of 10 birds had been overlooked. The last multi-observer record of this species was in 1978, and it is recommended that the species' IUCN Red List status of "Critically Endangered" is tagged as "Possibly Extinct". During these surveys, the population densities of seven bird species were calculated from 352 independent point counts. Causes of imprecision and bias were investigated, suggesting a small underestimation. Other species were recorded too infrequently, or their distributions were too biased, for analysis. The population densities of the extant endemic taxa were relatively high and suggest no current declines, and the population estimates were consistent with previous studies. This study recommends monitoring most species by point counts, or line transects if resources are limited, supplemented with specific monitoring of Tasman (Norfolk Island) Parakeet Cyanoramphus cookii, Pacific Robin Petroica multicolor, Southern Boobook Ninox novaeseelandiae and seabirds. Ongoing monitoring of these birds is needed to help inform management of the National Park and the island in general, given their small population sizes and their likely susceptibility to rat and cat predation, competition from alien species and drought.

\section{Introduction}

Norfolk Island is a $34.6 \mathrm{~km}^{2}$ island in the Tasman Sea between Brisbane and Auckland. It is a selfgoverning territory of Australia with a population of about 2,00o people. It supports four bird species and four subspecies endemic to the island and is therefore identified as an Endemic Bird Area (Stattersfield et al. 1998). An additional three endemic species and four endemic subspecies have become extinct since European colonisation in 1788, of which the Norfolk Island Boobook Ninox novaeseelandiae undulata and Island Thrush Turdus poliocephalus poliocephalus became extinct in the 1970s and 1980s. These endemic and threatened species and high populations of breeding seabirds qualify the island as an Important Bird Area (Dutson et al. 2009). The key threats of predation by rats and cats, and weed encroachment into the small remaining areas of native vegetation continue but are being mitigated (Parks Australia 2008). The conservation status of most of these species is poorly known as there have been few estimates of population sizes or trends. There have been a number of qualitative reviews of species abundance (e.g. Schodde et al. 1983, Rooke 1986, M. Christian et al. pers. comm.) but only two studies have estimated population sizes for a range of species (Robinson 1988, 1997).

The White-chested (White-breasted) White-eye Zosterops albogularis is classified as "Critically Endangered" by IUCN/BirdLife International (BirdLife International 2011) and as Extinct by the Australian Government (Australian Government 2011). Four records during an intensive survey in 1978/1979 were the last multi-observer records (Schodde et al. 1983). Although previous formal searches in the 1980s (Hermes et al. 1986, Rooke 1986, Robinson 1988, Bell 
1990) failed to find the species, there has been a scatter of reports from the late 1970 to 2009 (Appendix 1). Unfortunately, the plumage of the White-chested White-eye is similar to that of the Silvereye Z. lateralis and most records are from observers new to Norfolk Island, casting doubt on some of these records.

To elucidate the status of the White-chested White-eye, I recorded birds at 352 point counts across Norfolk Island National Park. These point counts also enabled collection of population density data and reviews of the conservation status of all forest birds. Table 1 lists all bird species and their scientific names recorded in the National Park; taxonomy and nomenclature follows Christidis and Boles (2008) with the additional of the alternative name Norfolk Island Parakeet.

\section{Methods}

Surveys were restricted to Norfolk Island National Park which supported 141 ha of the 172 ha mapped as native vegetation on the island (Gilmour and Helman 1989) and from which most recent reports of White-chested White-eye derive. I spent a total of 104 hours in the park between 22 November and 12 December 2009, conducting point-surveys at 352 of the 761 rat bait stations, of which 195 were in native forest ( 141 ha) and 257 were in weedy forest ( 302 ha). No surveys were undertaken in the eucalyptus plantation ( $36 \mathrm{ha}$ ) or non-forest habitats ( $14 \mathrm{ha}$ ) comprising the rest of the park, nor any outside of the park. Another $23 \mathrm{~km}$ of line transects, of which $12 \mathrm{~km}$ were in native forest and $11 \mathrm{~km}$ in weedy forest, were analysed for White-chested White-eye only. The terrain was too rugged and the forest canopy too dense to use GPS to navigate a randomised stratified survey grid. The rat bait stations positioned about every $50 \mathrm{~m}$ along parallel routes and approximating to a 50-100 $\mathrm{m}$ grid offered a practical and regular, albeit less randomised, grid. As station positions were biased towards ridge tops, gullies, paths and boundaries, surveys were not undertaken along wide paths and boundaries where there appeared to be an edge effect such as open canopy or bordering non-forest habitats. Most of the 409 unsurveyed stations were in extensive weedy forest in the west and north of the park or along boundaries. Surveys were shifted up to $10 \mathrm{~m}$ from any stations positioned in dense undergrowth with very limited visibility. Surveys were repositioned further along the path or omitted if closer than $50 \mathrm{~m}$ from the preceding survey or if it was suspected that individual birds were duplicated from the preceding survey. The $50 \mathrm{~m}$ spacing was closer than generally recommended for variable circular plot surveys but was considered optimal for detecting White-chested White-eyes as this species was assumed to have vocalisations of similar loudness to those of the congeneric Silvereye and Slender-billed White-eye Z. tenuirostris, whose calls and songs were audible for at least $30 \mathrm{~m}$. The dominant habitat at each survey station was recorded. Sites dominated by Norfolk Island pine Araucaria hetereophylla, Norfolk Island palm Rhopalostylis baueri or mixed hardwood (rainforest) were pooled as 'native forest' $(n=195)$ based on Robinson's $(1988,1997)$ calculations of generally similar population densities in rainforest and palm forest. Habitats dominated by red guava Pisidium cattleianum or African olive Olea europaea cuspidata were analysed separately (Table 3) and pooled as 'weedy forest' $(n=157)$ with discussion of species with significantly different encounter rates. Separate analyses for the five types of dominant habitat would be imprecise as the habitats occurred in a finer-scale mosaic than bird distributions.

Each survey followed standard variable circular plot methods (Bibby et al. 2000). Sunrise was between $05 \mathrm{~h}_{10}-\mathrm{O}_{5} \mathrm{~h}_{40} \mathrm{O}$, and surveys were undertaken between $0_{5} \mathrm{~h}_{30}$ and $09 \mathrm{~h}_{30}$ or continued to 1 ohoo if the weather was overcast and cool but not undertaken in rain or wind above Beaufort scale 3 or 1o knots. All birds within a $20 \mathrm{~m}$ radius and within five minutes were recorded, noting species, distance, group size and whether heard or seen. Fledglings were excluded. For Norfolk Island Gerygone Gerygone modesta and Golden Whistler Pachycephala pectoralis xanthoprocta, nearly all males were judged to sing within any five minute period, and only records of singing birds were analysed. These were assumed to be all males based on the singing habits of Grey Gerygone G. igata and various Golden Whistler subspecies (Higgins and Peter 2002, Higgins et al. 2006). For Grey Fantail Rhipidura albiscapa pelzelni, most males and females were judged 
Table 1. Number of records and key causes of survey bias for each species.

\begin{tabular}{|c|c|c|c|c|}
\hline Species & Endemic? & Causes of bias & $\begin{array}{l}\text { No. } \\
\text { Records* }\end{array}$ & Analysed? \\
\hline $\begin{array}{l}\text { California Quail Callipepla } \\
\text { californica }\end{array}$ & Introduced & $\begin{array}{l}\text { Too few records (not a true } \\
\text { forest species). }\end{array}$ & 1 & $\mathrm{n}$ \\
\hline Red Junglefowl Gallus gallus & Introduced & $\begin{array}{l}\text { Many in gullies where } \\
\text { many survey stations sited. } \\
\text { Some feeding on bait at } \\
\text { survey stations }\end{array}$ & 38 & $\mathrm{n}$ \\
\hline Emerald Dove Chalcophaps indica & Introduced? & Too few records. & 1 & $\mathrm{n}$ \\
\hline White Tern Gygis alba & Native & $\begin{array}{l}\text { Canopy of emergent pines; } \\
\text { not counted. }\end{array}$ & na & $\mathrm{n}$ \\
\hline $\begin{array}{l}\text { Crimson Rosella Platycercus } \\
\text { elegans }\end{array}$ & Introduced & $\begin{array}{l}\text { Visual and aural records } \\
\text { combined. Some at nest } \\
\text { and under-recorded? } \\
\text { Possible observer avoidance. }\end{array}$ & 44 & $\mathrm{y}$ \\
\hline $\begin{array}{l}\text { Tasman (Norfolk Island) Parakeet) } \\
\text { Cyanoramphus cookii }\end{array}$ & $\begin{array}{r}\text { Endemic } \\
\text { species }\end{array}$ & $\begin{array}{l}\text { Visual and aural records } \\
\text { combined. Some at nest } \\
\text { and under-recorded? } \\
\text { Possible observer avoidance. } \\
\text { Too few records. }\end{array}$ & 13 & $\mathrm{y}$ \\
\hline $\begin{array}{l}\text { Sacred Kingfisher Todiramphus } \\
\text { sanctus norfolkiensis }\end{array}$ & $\begin{array}{l}\text { Endemic } \\
\text { subspecies }\end{array}$ & $\begin{array}{l}\text { Too few records } \\
\text { (not a true forest species). }\end{array}$ & 1 & $\mathrm{n}$ \\
\hline $\begin{array}{l}\text { Norfolk Island Gerygone Gerygone } \\
\text { modesta }\end{array}$ & $\begin{array}{l}\text { Endemic } \\
\text { species }\end{array}$ & $\begin{array}{l}\text { Some at nest and } \\
\text { under-recorded? }\end{array}$ & 207 & $\mathrm{y}$ \\
\hline $\begin{array}{l}\text { Golden Whistler Pachycephala } \\
\text { pectoralis xanthoprocta }\end{array}$ & $\begin{array}{l}\text { Endemic } \\
\text { subspecies }\end{array}$ & $\begin{array}{l}\text { Some males at nest } \\
\text { and not singing? }\end{array}$ & 121 & $\mathrm{y}$ \\
\hline $\begin{array}{l}\text { Grey Fantail Rhipidura albiscapa } \\
\text { pelzelni }\end{array}$ & $\begin{array}{l}\text { Endemic } \\
\text { subspecies }\end{array}$ & $\begin{array}{l}\text { Some at nest and } \\
\text { under-recorded? }\end{array}$ & 155 & $\mathrm{y}$ \\
\hline $\begin{array}{l}\text { Pacific Robin Petroica multicolor } \\
\text { multicolor }\end{array}$ & $\begin{array}{l}\text { Endemic } \\
\text { subspecies }\end{array}$ & $\begin{array}{l}\text { Often attracted to observer. } \\
\text { Called and sang infrequently. }\end{array}$ & 41 & $\mathrm{y}$ \\
\hline Silvereye Zosterops lateralis & Native & Visual and aural records & 155 & $\mathrm{y}$ \\
\hline $\begin{array}{l}\text { Slender-billed White-eye Zosterops } \\
\text { tenuirostris }\end{array}$ & $\begin{array}{l}\text { Endemic } \\
\text { species }\end{array}$ & $\begin{array}{l}\text { combined. Some at nest } \\
\text { and under-recorded? }\end{array}$ & 74 & $\mathrm{y}$ \\
\hline $\begin{array}{l}\text { Welcome Swallow Hirundo } \\
\text { neoxena }\end{array}$ & Native & Aerial; not counted. & na & $\mathrm{n}$ \\
\hline $\begin{array}{l}\text { Common Blackbird Turdus } \\
\text { merula }\end{array}$ & Introduced & $\begin{array}{l}\text { Many in gullies where many } \\
\text { survey stations sited. }\end{array}$ & 72 & $\mathrm{n}$ \\
\hline Song Thrush Turdus philomelos & Introduced & $\begin{array}{l}\text { Too few records (not a true } \\
\text { forest species). }\end{array}$ & 7 & $\mathrm{n}$ \\
\hline Common Starling Sturnus vulgaris & Introduced & $\begin{array}{l}\text { Sometimes attracted to } \\
\text { observer. Too few records } \\
\text { (not a true forest species). }\end{array}$ & 12 & $\mathrm{n}$ \\
\hline Common Greenfinch Chloris chloris & Introduced & $\begin{array}{l}\text { Too few records (not a true } \\
\text { forest species). }\end{array}$ & 2 & $\mathrm{n}$ \\
\hline
\end{tabular}

${ }^{*}$ Records exclude fledglings and, for Norfolk Island Gerygone and Golden Whistler, non-singing (presumed female) birds. Additional species recorded between point counts were Nankeen Kestrel Falco cenchroides, Shining Bronze-Cuckoo Chalcites lucidus, Southern Boobook Ninox novaeseelandiae undulata, White-throated Needletail Hirundapus caudacutus, House Sparrow Passer domesticus and European Goldfinch Carduelis carduelis.

to sing or call within any five minute period, based on pre-survey assessments and Higgins et al. (2006), and each vocal adult was recorded separately. For Crimson Rosella Platycercus elegans, Tasman (Norfolk Island) Parakeet Cyanoramphus cookii, Silvereye and Slender-billed Whiteeye, most birds were judged to call within any five minute period but any visual records of silent 
birds were combined with vocal records for analysis. For these three species, a mean group size was estimated from the observed group sizes, including additional observations outside of the point counts.

The probability of overlooking an extant population of White-chested White-eye was calculated using the formula in Scott et al. (2008):

$$
P(X=0 ; N=k)=(1-E / A)^{k}
$$

where $P=$ probability that populations of a given size are missed; $X=$ number of birds detected in a survey; $\mathrm{N}=$ population size; $\mathrm{E}=$ total effective survey area within $\mathrm{A}=$ total range of the species.

Based on field experience of many congeneric species, I judged the detectability of the species to be similar to that of the sympatric Slender-billed White-eye, and less than that of the more vocal Silvereye. I therefore used an effective detection distance as $13 \mathrm{~m}$, based on $13 \mathrm{~m}$ for Slender-billed White-eye and $15 \mathrm{~m}$ for Silvereye in native forest, as calculated below. Many of the line-transects were along rough terrain and I conservatively estimated a mean effective detection distance of $5 \mathrm{~m}$ each side of the route. I therefore applied an effective detection area of 10.8 ha from all point counts and 12 ha from line transects, in a total native forest area of 141 ha. I also spent 21 hours on repeat surveys along some access tracks between 05hoo-10hoo; assuming an average walking speed of $1 \mathrm{~km}$ hour ${ }^{-1}$ and detection distance of $5 \mathrm{~m}$, this would increase the effective detection area by 21 ha. An additional 31 hours of non-standardised observations were made in the National Park and not used in these calculations. As most records of White-chested White-eyes have been singles (Higgins et al. 2006), a group size of one was assumed.

Other data were analysed using the multiple covariate distance sampling of the Distance program, version 6.o (Thomas et al. 2009). For Norfolk Island Gerygone, Golden Whistler and Grey Fantail, which were recorded aurally, a uniform detection $(\mathrm{p})=\mathrm{I}$ (i.e. all birds in the survey area were detected) was modelled and used. For the parrots and white-eyes, which were usually both seen and heard, visual and aural records were combined. Visual and aural records have different detectabilities but the combined detectability functions modelled by Distance were robust. As the detectability of Tasman (Norfolk Island) Parakeet $(n=13$ records) was judged to be very similar to that of the Crimson Rosella $(n=44)$, these species were combined to create a composite detectability function which approximated to a uniform detection $(\mathrm{p})=1$, then poststratified to generate separate density estimates. For Silvereye and Slender-billed White-eye, which were recorded both visually and aurally, detectability dropped off sharply to $(p)=0.15$ at $20 \mathrm{~m}$ and an effective detection distance of $13.3 \mathrm{~m}$ and $15.2 \mathrm{~m}$ respectively. The detection distance was truncated at $20 \mathrm{~m}$ and stratified into six equal intervals to smooth out any clumping in distance estimates. The best detectability model offered by Distance was chosen based on an examination of AIC, detectability histogram and goodness of fit tests, especially at closer distances. Detectability functions for native and weedy forest were found to be very similar and pooled, but the data were post-stratified into native and weedy forest to calculate separate density estimates. The mean group size of Crimson Rosella, Tasman (Norfolk Island) Parakeet and Silvereye was estimated as 2.0, that of Slender-billed White-eye as 2.5, and other non-flocking species as 1.o. Population estimates were generated by multiplying the density estimates for native and weedy forest by the area of these habitats in the National Park.

\section{Results}

I recorded no possible White-chested White-eyes. Figure 1 indicates the probability of overlooking various population sizes of White-chested White-eye in native forest in the National Park, calculated from the 'unique' point counts and line transects, and also from the total time spent surveying in suitable habitat including repeat surveys. This calculates, for instance, a probability 


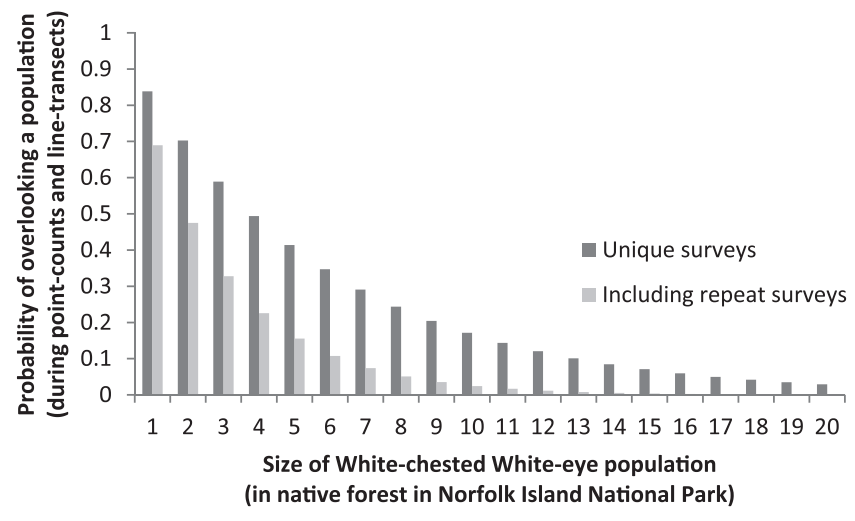

Figure 1. Probability of overlooking a population of White-chested White-eye.

of $15-41 \%$ that I overlooked a population of five birds and a $2-17 \%$ probability that I overlooked a population of 10 birds.

In total 944 records of 24 species were collected in the 352 point-counts, as summarised in Table 1. For all except seven species, there were insufficient records to calculate detectabilities, or too many biases were detected to allow accurate analysis. Most biased species did not vocalise regularly, Red Junglefowl Gallus gallus and Common Blackbird Turdus merula were biased towards damper gullies with deep leaf-litter where many survey stations were located, and Pacific Robins Petroica multicolor were often overlooked unless moving close to investigate the observer. The population densities estimated by Distance and population estimates for these seven species are given in Table 2.

\section{Discussion}

\section{Population densities}

Population densities and estimates were calculated with reasonable confidence for six species within Norfolk Island National Park: two endemic species, two endemic subspecies, one native species and one introduced species (Table 2). Estimates were not extrapolated across the island as many species also occurred in areas not mapped as forest remnants, the area of weedy forest was poorly known, much of the native forest was dissimilar to that in the park.

These estimates show that these six species survive at moderately high population densities. Previous population density estimates on Norfolk Island (Robinson 1987, 1988) used different

Table 2. Estimated population densities of analysed species.

\begin{tabular}{lllll}
\hline Species & $\begin{array}{l}\text { Density and } \\
95 \% \text { confidence } \\
\text { limits in native forest }\end{array}$ & $\begin{array}{l}\text { Density and 95\% } \\
\text { confidence limits in } \\
\text { weedy forest }\end{array}$ & Units / ha & $\begin{array}{l}\text { Population } \\
\text { estimate } / \\
\text { total birds* }\end{array}$ \\
\hline Crimson Rosella & $1.1(0.6-2.2)$ & $1.5(0.7-3.0)$ & Group size $=2$ & 1,200 \\
Norfolk Island Gerygone & $6.3(4.7-8.5)$ & $3.4(2.2-5.2)$ & Males & 3,800 \\
Golden Whistler & $2.8(1.8-4.3)$ & $2.5(1.5-4.1)$ & Males & 2,200 \\
Grey Fantail & $5.0(3.6-6.9)$ & $2.9(1.9-4.6)$ & Adults & 1,600 \\
Silvereye & $5.4(3.9-7.5)$ & $4.5(3.1-6.5)$ & Group size $=2$ & 4,200 \\
Slender-billed White-eye & $3.5(2.3-5.4)$ & $3.7(2.3-5.9)$ & Group size $=2.5$ & 4,000 \\
\hline
\end{tabular}

*In 443 ha of National Park, excluding 36 ha of eucalyptus plantation and 14 ha of non-forest habitat. See discussion for methodological biases, noting that most species are underestimated. 
Table 3. Encounter rates (records / point count) in weedy forest dominated by African olive and red guava.

\begin{tabular}{lcllllll}
\hline & $\begin{array}{l}\text { Sample } \\
\text { size }(n)\end{array}$ & $\begin{array}{l}\text { Crimson } \\
\text { Rosella }\end{array}$ & $\begin{array}{l}\text { Norfolk Is } \\
\text { Gerygone }\end{array}$ & $\begin{array}{l}\text { Golden } \\
\text { Whistler }\end{array}$ & Grey Fantail & Silvereye & $\begin{array}{l}\text { Slender-billed } \\
\text { White-eye }\end{array}$ \\
\hline African olive & 21 & 0 & 0.61 & 0.42 & 0.29 & 0.76 & 0.05 \\
Red guava & 136 & 0.13 & 0.53 & 0.32 & 0.38 & 0.43 & 0.22 \\
\hline
\end{tabular}

methods so the imprecision and bias in each method need to be compared before any population trends can be concluded. However, these population densities are relatively high compared to congeners on similar small islands (pers. obs.), suggesting that they have not been affected by any recent or current threat.

\section{Causes of imprecision and bias}

All Grey Fantails, male Norfolk Island Gerygones and male Golden Whistlers were assumed to vocalise within any five minute survey. A pre-survey assessment estimated that fewer than 10\% additional birds were present but silent, and longer surveys would overestimate numbers as additional birds moved in from outside the survey area.

Most Norfolk Island Gerygones had fledglings but only one or two Golden Whistler, Grey Fantail, Silvereye and Slender-billed White-eye fledglings were seen; Silvereye and Slender-billed White-eye were also seen building and attending nests. It is assumed that some adults would have been overlooked at the nest. The inter-survey distance of as little as $50 \mathrm{~m}$ may have led to duplicate counts of some individual birds, and results for the rarest birds such as Tasman (Norfolk Island) Parakeet may have been biased by stochastic irregularity in distribution.

There was a higher encounter rate for Silvereye and lower encounter rate for Slender-billed White-eye in African olive than red guava. These habitats were not mapped separately but African olive dominated much of the unsurveyed sections of the park (pers. obs.). If African olive dominated $50 \%$ of the weedy forest in the park, compared to dominating $13 \%$ of the weedy forest surveys, then the overall population of Silvereye may have been underestimated by $20 \%$ and that of Slender-billed White-eye overestimated by $20 \%$. The extent and quality of the native forest has increased by an unquantified amount since the last mapping (Gilmour and Helman 1989) which would cause under-estimation of species which are more common in native forest than weedy forest, notably the Norfolk Island Gerygone.

Distances were estimated by eye and regularly calibrated by measuring with standard paces. Imprecision was estimated as within 10\%, rarely $20 \%$, but without bias. Accuracy of bird identification was judged to be close to $100 \%$ except that a few Slender-billed White-eyes and Silvereyes may have been overlooked in mixed groups of these species.

In conclusion, populations of all species were potentially underestimated for various reasons and Slender-billed White-eye was potentially overestimated if the weedy forest had more African olive.

\section{Comparison with previous estimates}

The two previous estimates of population density were based on the assumption of $100 \%$ detectability along a total of $3 \mathrm{~km}$ of transect of $20 \mathrm{~m}$ width walked at $1.5 \mathrm{~km} \mathrm{~h}^{-1}$ (Robinson 1988, 1997). In contrast, the 2009 methods reduced the bias from silent birds by watching for five minutes, and from reduced detectability away from the observer by using Distance detectability functions. Therefore, densities calculated from point counts would be expected to be significantly higher. To test this expectation, a total of $3.5 \mathrm{~km}$ of transect was surveyed in 2009 along Robinson's native forest routes. Table 4 compares the various densities and shows that the 2009 point counts indeed calculated much higher densities than the 2009 line transects. The results of the 2009 line transects are consistent with those from 1987 and 1996 but the sample size is too 
Table 4. Population densities of forest birds (adult birds ha' ${ }^{-1}$ ) in native and weedy forest in 1987, 1996 and 2009 .

\begin{tabular}{llllllll}
\hline Species & $\begin{array}{l}\text { Native } \\
1987 \\
\text { (transect) }\end{array}$ & $\begin{array}{l}\text { Native } \\
1996 \\
\text { (transect) }\end{array}$ & $\begin{array}{l}\text { Native } \\
2009 \\
\text { (transect) }\end{array}$ & $\begin{array}{l}\text { Native } \\
2009 \\
\text { (Distance) }\end{array}$ & $\begin{array}{l}\text { Weedy } \\
1987 \\
\text { (transect) }\end{array}$ & $\begin{array}{l}\text { Weedy } \\
1996 \\
\text { (transect) }\end{array}$ & $\begin{array}{l}\text { Weedy } \\
2009 \\
\text { (Distance) }\end{array}$ \\
\hline Crimson Rosella & 0.8 & 0.4 & 0.8 & 2.2 & 1.1 & 1.1 & 2.9 \\
NI Gerygone & 1.9 & 2.1 & 1.5 & 12.6 & 1.5 & 1.7 & 6.8 \\
Golden Whistler & 2.8 & 1.9 & 1.0 & 5.6 & 1.9 & 1.1 & 5.0 \\
Grey Fantail & 2.7 & 1.9 & 0.9 & 5.0 & 0.7 & 1.4 & 2.9 \\
Silvereye & 3.0 & 3.3 & 2.0 & 10.8 & 4.3 & 5.5 & 9.0 \\
Slender-billed White-eye & 2.8 & 3.8 & 1.7 & 8.8 & 3.1 & 1.1 & 9.3 \\
\hline
\end{tabular}

Native 1987 and 1996 = mean of population densities in rainforest and palm forest in Robinson (1988, 1997). Weedy 1987 and 1996 = population densities in olive forest in Robinson $(1988,1997)$.

small to allow meaningful comparison. The dry weather in October-December $2009(54 \mathrm{~mm}$ rainfall compared to the mean of $244 \mathrm{~mm}$ between 1890 and 2009, after the driest August on record; BOM 2010) may have affected results. Future monitoring could be undertaken as transects along the main paths. This would be more practicable than point counts at rat bait stations and would generate a robust population index, but not absolute densities even if modelled with Distance, given the bias of edge-effects along the paths.

\section{White-chested White-eye}

The probability estimates of overlooking any White-chested White-eyes are based on a number of assumptions, notably that their detectability is similar to that of Slender-billed White-eye, any remaining birds are restricted to native forest, and are distributed equally across the area. The detectability may be lower than modelled here as White-chested White-eye is reported to seldom call (Higgins et al. 2006) although it is also reported to call loudly when in flocks and occasionally sing (Bassett Hull 1909). Most records have been from rainforest and only a few from disturbed or weedy forest (Higgins et al. 2006), but including orchards (Bassett Hull 1909) and a coastal olive thicket within the National Park (Mees 1969) and there have been no reports from weedy forest in recent years (R. Hill in litt. 2010). Moreover, most records originate from the small area between the summits of Mt Pitt and Mt Bates, which was surveyed to varying degrees 36 times during this study, but only one survey was entered into the probability calculations based on 'unique' surveys. However, if birds survive in the 300 ha of weedy forest in the National Park and contiguous areas on private land, there would be a much higher probability of overlooking these birds $(P=38 \%$ chance of overlooking a population of 1 o birds across all native and weedy forest in the park).

Considering these surveys, calculations, assumptions and biases, it seems reasonable to conclude that any surviving population of White-chested White-eye is tiny. The last records by multiple observers were in 1978 (Schodde et al. 1983) and it is difficult to know which subsequent records (listed in Appendix I) are genuine given that none has any supporting evidence. Given these ongoing unconfirmed reports, it would be premature to declare the species Extinct, but, as noted in Garnett et al. (2011a) using information published here, it is thought to qualify for the IUCN Red List status of "Critically Endangered (Possibly Extinct)". This tag was defined by Butchart et al. (2006) for species that are, on the balance of evidence, likely to be extinct, but for which there is a small chance that they may be extant and thus should not be listed as "Extinct" until there have been adequate surveys. White-chested White-eye qualifies as "Possibly Extinct" based on its documented decline from before the 1960s, the threatening processes of rats introduced in the 1940s and possibly competition with Silvereye which colonised in 1904, its predisposition to extinction including its tiny range and the extinction of congeners on nearby 
Lord Howe Island (Hindwood 1940) and the number of negative surveys since 1978. Any future records need to be supported by as much evidence as possible and submitted to the National Park and Birds Australia Rarities Committee.

\section{Conservation status of other endemic taxa}

The Tasman (Norfolk Island) Parakeet was categorised as "Critically Endangered" (DI) based on $<250$ individuals, possibly declining (Garnett et al. 2011a). The 13 records of Tasman (Norfolk Island) Parakeet do not enable a precise population estimate (mean $=240 ; 95 \%$ confidence limits 45-807). It has clearly increased from its population nadir of only four breeding females in 1994 (Lane et al. 1998) but the Parks Australia estimation that the population could be 200 birds based on the survival and longevity of birds known to have fledged from monitored nest sites (P. Olsen per C. Rowston pers. comm. 2009) needs confirmation, as undetected declines in such a small population could prove fatal for the species (Garnett et al. 2011a). A dedicated survey across the island is needed to improve the confidence of these estimates. Crimson Rosellas compete with Tasman (Norfolk Island) Parakeets for nest hollows (Hill 2002) and probably food, and have been controlled around parakeet nest sites. The ongoing impacts of increasing numbers of Crimson Rosellas should be investigated or they should be eradicated. The local population of Southern Boobook Ninox novaeseelandiae undulata, which is derived from a single female of the endemic N. n. undulata and an introduced male of N. n. novaeseelandiae (Garnett et al. 2011b), was also categorised as "Critically Endangered" (D) by Garnett et al. (2011a) as the population was estimated as $<50$ individuals; this 2009 study did not estimate the population size of this nocturnal taxon.

The endemic subspecies of Pacific Robin Petroica multicolor multicolor was categorised as "Endangered" (B1abii,v+B2abii,v, C2aii) by Garnett et al. (2011a) based on a small population that appeared to be declining. The 2009 survey was heavily biased by birds flying closer to investigate the observer, especially in dense red guava-dominated weedy forest, as indicated by 13 visual records at $\mathrm{O}-5 \mathrm{~m}, 11$ at $6-10 \mathrm{~m}$ and 2 at $11-20 \mathrm{~m}$, compared to six aural records at $\mathrm{O}-1 \mathrm{O} \mathrm{m}$ and 9 at 10-20 m. Distance therefore overestimated the population density; as 1.9 (1.0-3.5) birds $\mathrm{ha}^{-1}$ in native forest and $8.7(5.6-13.7)$ birds $\mathrm{ha}^{-1}$ in weedy forest. Robinson (1997) resurveyed 34 Pacific Robin territories originally mapped by Major (1989) and used song playback along transects to estimate population densities of $0.17^{-1.3}$ pairs ha ${ }^{-1}$ in various habitats and a total of 520 pairs in the National Park in 1987 and 440 pairs in 1996. A high rate of fledging success was noted in 2009 with a total of 24 juveniles, 42 females or first-year males and 12 adult males; Robinson $(1986,1997)$ recorded that about $36 \%$ pairs reared fledglings.

The Norfolk Island Gerygone, Slender-billed White-eye and the endemic subspecies of Golden Whistler and Grey Fantail were categorised as "Near Threatened" (D2) based on their restriction to one very small location with a plausible but low probability threat (Garnett et al. 2011a). These categorisations are supported by this 2009 study suggesting populations $>1,000$ individuals with no significant population declines. The endemic subspecies of Sacred Kingfisher Todiramphus sanctus norfolkiensis was categorised as "Near Threatened" $\left(D_{1+2}\right)$ as the population was estimated as close to 1,000 individuals; its largely non-forest population was not assessed by this 2009 study, but at least three pairs were noted on the $2 \mathrm{~km}^{2}$ Phillip Island (pers. obs).

\section{Population trends of introduced bird species}

Three introduced bird species were encountered in significant numbers: 72 records of Common Blackbird, 44 of Crimson Rosella and 38 of Red Junglefowl (Table 1). The records of Crimson Rosella were considered to be unbiased and extrapolated to an estimated population of 1,200 individuals in the National Park (Table 2). Numbers of this species have not previously been estimated but a comparison with the literature (notably the distribution maps and anecdotal discussion of abundance in Schodde et al. 1983) suggests that this species has increased 
significantly, with implications for the conservation of Tasman (Norfolk Island) Parakeets. The surveys of Red Junglefowl and Common Blackbird were biased by these species' preference for gullies, where many of the survey sites were located. These species had very high population densities within these gullies, and may have ecological impacts for instance on leaf-litter invertebrates (Director of National Parks 2010).

\section{Monitoring and conservation needs}

The Norfolk Island Region Threatened Species Recovery Plan (Director of National Parks 2010) specifically undertakes to "establish monitoring surveys that are adequate to indicate changes in populations of threatened endemic bird taxa". Specific bird monitoring has yet to be implemented except for some monitoring of nest success at Tasman (Norfolk Island) Parakeet and Southern Boobook nests, and for maintaining these rat-proof nesting hollows. Monitoring of rat and cat numbers is particularly important given their role in the extinctions of many closely related bird taxa, notably on neighbouring Lord Howe Island (McAllan et al. 2004). Extensive rat control measures have been established on Norfolk Island National Park based on bait stations across an approximate 50-100 m grid. Cat trapping is ongoing across the park. However rat and cat control are only partially effective and the best actions would be to eradicate rats and feral cats from across the island. This has the general support of the National Park and island community but lacks funding. Norfolk Island was assessed as the eleventh highest global priority for vertebrate eradications by Brooke et al. (2007).

Norfolk Island National Park also includes Phillip Island which is slowly recovering its vegetative cover, with implications for some of the seabirds that nest there. The island is one of only two breeding sites for two globally "Vulnerable" seabirds, Providence Petrel Pterodroma solandri and White-necked Petrel P. cervicalis. Very small populations of both petrels persist on Phillip Island, but their population trend is unknown and still in need of monitoring; as well as the need to maintain strong bio-security.

\section{Conclusions}

This study suggests that five-minute point-surveys are suitable for monitoring Norfolk Island Gerygone, Golden Whistler and Slender-billed White-eye. These endemic taxa are present in higher numbers than previously estimated and their conservation status is slightly more secure than previously assessed. This may be a result of the ongoing actions within the park to control rats and cats and to restore native vegetation, but these actions need continual investment, and plans to eradicate rats from across the island group should be supported. Tasman (Norfolk Island) Parakeets were recorded too infrequently to allow a precise population estimate, and need a specific survey across the island. The impact of increasing numbers of Crimson Rosellas that compete with Tasman (Norfolk Island) Parakeets for nest sites also needs to be investigated, as do the high numbers of Red Junglefowl (Table 1 ) which may be impacting the forest floor ecology and invertebrates (Director of National Parks 2010). Ongoing monitoring of Crimson Rosella, Red Junglefowl, California Quail Callipepla californica and Common Starling Sturnus vulgaris is needed as part of the proposed action to "manage introduced birds to reduce impact on threatened species" (Director of National Parks 2010).

Additional species-specific surveys are needed for Pacific Robin, which is believed to be declining, especially outside the park, Southern Boobook, which has a very small population, and seabirds, as well as Tasman (Norfolk Island) Parakeet (discussed above). Further surveys are clearly desirable for White-chested White-eye, perhaps earlier in the season than these 2009 surveys which recorded many singing Slender-billed White-eyes and Silvereyes but also some nest-building and fledglings; the breeding season of White-chested White-eye is October to December (Mathews 1928). These species-specific and forest bird monitoring programmes are an 
essential component of the National Park management, to indicate the best management actions for the island's birds, and to identify which species need specific and immediate help to prevent further extinctions.

\section{Acknowledgements}

I am very grateful to the BirdLife International / BirdFair Preventing Extinctions Project and the BirdFair / RSPB Research Fund for Endangered Birds for covering the costs of fieldwork, and to Coral Rowston and colleagues at Parks Australia and Margaret Christian of the Norfolk Island Flora and Fauna Society for facilitating my research. Doug Robinson kindly advised about his surveys, Simon Watson advised about Distance, and Stuart Butchart, Stephen Garnett, Ron Hill and Penny Olsen made very helpful comments on the manuscript.

\section{References}

Anon. (1997) Bird sightings. Norfolk Nature Notes 12: 459.

Anon. (1998) Bird sightings. Norfolk Nature Notes 13: 478-9.

Australian Government (2011) Zosterops albogularis - White-chested White-eye, Norfolk Island Silvereye. Downloaded from http://www.environment.gov.au/cgi-bin/ sprat/public/publicspecies.pl?taxon_id $=25899$ on $27 / 1 / 2011$.

Bassett Hull, A. F. (1909) The Birds of Lord Howe and Norfolk Islands. Proc. Linn. Soc. NSW 34: 636-693.

Bell, B. D. (1990) The status and management of the White-breasted White-eye and other birds on Norfolk Island. Canberra: Unpublished Report to Australian National Parks and Wildlife Service.

Bibby, C. J., Burgess, N. D. and Hill, D. A. (200o) Bird census techniques. London: Academic Press.

BirdLife International (2011) Species factsheet: Zosterops albogularis. Downloaded from http://www.birdlife.org on 02/02/2011.

BOM (2010) Climate statistics for Norfolk Island. Downloaded from http://www.bom. gov.au/jsp/ncc/cdio/cvg/av on 12/01/2010.

Brooke, M. de L., Hilton, G. M. and Martins, T. L. F. (2007) Prioritizing the world's islands for vertebrate-eradication programmes. Anim. Conserv. 380: 380-390.

Butchart, S. H. M, Stattersfield, A. J. and Brooks, T. M. (2006) Going or gone: defining "Possibly Extinct" species to give a truer picture of recent extinctions. Bull. Brit. Orn. Club 126: 7-24.
Christidis, L. and Boles, W. E. (2008) Systematics and taxonomy of Australian birds. Collingwood, Australia: CSIRO Publishing.

Director of National Parks (2010) Norfolk Island region threatened species recovery plan. Canberra: Department of the Environment, Water, Heritage and the Arts.

Dutson, G., Garnett, S. and Gole, C. (2009) Australia's Important Bird Areas. Melbourne: Birds Australia. (RAOU Conservation Statement no. 14).

Garnett, S. T. and Crowley, G. M. (2000) The action plan for Australian birds 2000. Canberra: Environment Australia.

Garnett, S. T., Olsen, P., Butchart, S. H. M. and Hoffmann, A. A. (2011b) Did hybridisation save the Norfolk Island Boobook Owl or cause its extinction? Oryx 45: 500-504

Garnett, S. T., Szabo, J. K. and Dutson, G. (2011a) The action plan for Australian birds 2010. Collingwood, Australia: CSIRO.

Gilmour, P. and Helman, C. (1989) The vegetation of Norfolk Island National Park. Canberra: Australian National Parks and Wildlife Service.

Hermes, N. (1985) Birds of Norfolk Island. Norfolk Island: Wonderland Publications.

Hermes, N., Evans, O. and Evans, B. (1986) Norfolk Island birds: a review 1985. Notornis 33: 141-149.

Higgins, P. J. and Peter, J. M., eds. (2002) Handbook of Australian, New Zealand and Antarctic birds. Volume 6: Pardalotes to shrike-thrushes. Melbourne: Oxford University Press. 
Higgins, P. J., Peter, J. M. and Cowling, S. J., eds. (2006) Handbook of Australian, New Zealand and Antarctic birds. Volume 7: Boatbill to starlings. Melbourne: Oxford University Press.

Hill, R. (2002) Recovery plan for the Norfolk Island Green Parrot Cyanoramphus novaezelandiae cookii. Canberra: Natural Heritage Trust.

Hindwood, K. A. (1940) The birds of Lord Howe Island. Emu. 40: 1-86.

Lane, B. A., Bezuijen, M. R., Greenwood, D., Carr, G. W. and Ward, R. (1998) 1998 recovery plan for Norfolk Island Parrot (Cyanoramphus novaezelandiae cookii). Melbourne: Ecology Australia Pty Ltd.

Major, R. (1989) Reproductive output and recruitment of the Norfolk Island Scarlet Robin (Petroica multicolor multicolor). Phase II. Canberra: Australian National Parks and Wildlife Service. Unpublished report.

Mathews, G. M. (1928) The birds of Norfolk and Lord Howe Islands and the Australian South Polar Quadrant. London: Witherby.

McAllan, I. A. W., Curtis, B. R., Hutton, I. and Cooper, R. M. (2004) The birds of the Lord Howe Island Group: a review of records. Austral. Field Ornith. 21:1-82.

McKean, J. L., Evans, O. and Lewis, J. H. (1976) Notes on the birds of Norfolk Island. Notornis 23: 299-301.

Mees, G. F. (1969) A systematic review of the Indo-Australian Zosteropidae (Part III). Zool. Verhandelingen 102: 1-381.

Moore, J. L. (1981) Norfolk Island notes 1971 to 1980. Notornis 28: 50-56.

Moore, J. L. (1999) Norfolk Island bird notes 1977 to 1997. Notornis 46: 354-364.

Parks Australia (2008) Norfolk Island $\mathrm{Na}$ tional Park and Norfolk Island Botanic Garden: management plan 2008-2018. Canberra: Parks Australia.

Robinson, D. (1988) Ecology and management of the Scarlet Robin, White-breasted White-eye and Long-billed White-eye on Norfolk Island. Report to the Australian National Parks and Wildlife Service, Canberra. Unpublished report.
Robinson, D. (1997) An evaluation of the status of the Norfolk island Robin following rat-control and weed-control works in the Norfolk island National Park. Canberra: Environment Australia. Unpublished report.

Rooke, I. (1986) Survey of the Whitebreasted White-eye and the Norfolk Island Boobook Owl on Norfolk Island, October - November 1985. Melbourne: Royal Australasian Ornithologists' Union. (RAOU Report No. 20).

Schodde, R., Fullagar, P. and Hermes, N. (1983) A review of Norfolk Island birds: Past and present. Canberra: Australian National Parks and Wildlife Service.

Scott, J. M., Ramsey, F. L., Lammertink, M., Rosenberg, K. V., Rohrbaugh, R., Wiens, J. A. and Reed, J. M. (2008) When is an "extinct" species really extinct? Gauging the search efforts for Hawaiian forest birds and the Ivory-billed Woodpecker. Avian Conserv. Ecol. - Écologie et conservation des oiseaux 3:3. http://www.ace-eco.org/ $\mathrm{vol}_{3} /$ iss $_{2} / \mathrm{art}_{3} /$

Smithers, C. N. and Disney, H. J. de S. (1969) The distribution of terrestrial and freshwater birds on Norfolk Island. Austral. Zoologist 15: 127-140.

Stattersfield, A. J., Crosby, M. J., Long, A. J. and Wege, D. C. (1998) Endemic Bird Areas of the World: Priorities for biodiversity conservation. Cambridge, UK: BirdLife International. (Birdlife Conservation Series No. 7).

Thomas, L., Laake, J. L., Rexstad, E., Strindberg, S., Marques, F. F. C., Buckland, S. T., Borchers, D. L., Anderson, D. R., Burnham, K. P., Burt, M. L., Hedley, S. L., Pollard, J. H., Bishop, J. R. B. and Marques, T. A. (2009) Distance 6.o. Release 2. St Andrews, UK: Research Unit for Wildlife Population Assessment. http://www.ruwpa.st-and.ac.uk/ distance/

Waugh, P. (1988) Sightings of the Whitechested White-eye. Norfolk Nature Notes 4: $252-253$. 


\section{GUY DUTSON}

Biodiversity Solutions, clo 15 Wills Close, Corfe Mullen, Dorset BH21 3 SR, UK.

*Author for correspondence; e-mail: guydutson@gmail.com

Received 7 February 2011; revision accepted 23 December 2011;

Published online 9 March 2012

Appendix 1. Records of White-chested White-eye No records since the original specimens have any supporting evidence such as published descriptions, photographs or sound recordings. All published records are summarised below.

\begin{tabular}{|c|c|c|}
\hline Year & Numbers and notes & Reference \\
\hline & $\begin{array}{l}\text { "Very plentiful"; much more common than } \\
\text { Slender-billed White-eye }\end{array}$ & Bassett Hull (1909) \\
\hline 1926 & Twelve specimens taken in one week & $\begin{array}{l}\text { Correia (unpubl. ms) in } \\
\text { Mees (1969) }\end{array}$ \\
\hline 1962 & $\begin{array}{l}\text { Three singles in National Park in two } \\
\text { weeks; population estimated to be less } \\
\text { than } 50 \text { birds }\end{array}$ & Mees (1969) \\
\hline 1968 & Two in rainforest in two weeks survey & Smithers and Disney (1969) \\
\hline 1974 & Two near Botanic Gardens & J. Forshaw in Rooke (1986) \\
\hline 1975 & One pair in National Park & McKean et al. (1976) \\
\hline 1978 & Two in National Park & Moore (1981) \\
\hline 1978 & $\begin{array}{l}\text { Recorded in four survey squares in one } \\
\text { week survey by } 60 \text { observers; all in tall } \\
\text { forest and all except one in National Park }\end{array}$ & Schodde et al. (1983) \\
\hline 1979 & One in National Park & P. Coyne in Rooke (1986) \\
\hline 1980 & Three in National Park & Moore (1981) \\
\hline 1987-1994+ & $\begin{array}{l}\text { A series of records at Bumbora; other } \\
\text { records after } 1994 \text { not published }\end{array}$ & $\begin{array}{l}\text { Waugh (1988), Bell (1990), } \\
\text { Moore (1999), H. McCoy } \\
\text { pers. comm. (2009) }\end{array}$ \\
\hline 1991 & Two in National Park & Moore (1999) \\
\hline 1997 & One on Bates Track in National Park & Anon. (1997) \\
\hline 1998 & $\begin{array}{l}\text { Two records of singles on Bates Track in } \\
\text { National Park }\end{array}$ & Anon. (1998) \\
\hline 2000 & One at McLachlans Ridge in National Park & $\begin{array}{l}\text { R. Ward in Garnett \& Crowley (2000) } \\
\text { and in litt. } 2010\end{array}$ \\
\hline 2005 & $\begin{array}{l}\text { Two records, perhaps the same individual, } \\
\text { in National Park }\end{array}$ & M. Christian et al. (pers.comm.) \\
\hline
\end{tabular}

Numerous undocumented reports include sightings reported to the National Park as recently as 2009 (C. Rowston in litt. 2009). Negative records include Hermes et al. (1986) who worked in the National Park 1983-1985, Rooke (1986) who spent three weeks surveying for the species, Robinson (1988) and Bell (1990) who each spent eight weeks surveying for the species. These authors and Hermes (1985) concluded that the species was extinct. Additionally, many birdwatchers visit Norfolk Island and search for the species annually without success. 